\title{
DENTAL ANOMALIES IN THE ATLANTIC POPULATION OF SOUTH AMERICAN SEA LION, OTARIA BYRONIA (PINNIPEDIA, OTARIIDAE): EVOLUTIONARY IMPLICATIONS AND ECOLOGICAL APPROACH
}

\author{
César Jaeger Drehmer ${ }^{1,2}$, Marta Elena Fabián ${ }^{2,3}$ and João Oldair Menegheti ${ }^{3}$
}

\begin{abstract}
We analyzed 63 cases of dental anomalies from 62 specimens of a total sample of 516 specimens of the Atlantic population of South American sea lions, Otaria byronia de Blainville, 1820. The anomalies were represented by 53 cases of missing upper post-canine 6 (second molars), seven cases of maxillary or mandibular extra teeth, two cases of "dentes geminati" and one case of reduced teeth. Considering a phylogenetic framework where all otariid species and basal Pinnipedimorpha are included, missing post-canine 6 could be related to evolutionary trends in Otariidae towards a progressive reduction and loss of teeth (agenesis). The occurrence of the upper post-canine 6 in Otaria Péron, 1816 as in Phocarctos Peters, 1866 is usually regarded as a primitive character. Alternatively, when adopting another cladistic procedure, this could be interpreted as a taxic atavism at the base of Otaria/Phocarctos clade. Extra-mandibular teeth are related to a concrete case of spontaneous atavism in the dentition of Otaria byronia, in retrogression to ancient groups like the Miocene pinnipediform Pteronarctos Barnes, 1989. The other anomalies - maxillary extra teeth, "dentes geminati" and reduced teeth - are caused by some disturbance on the epigenetic system underlying dental morphogenesis leading to duplication, coalescence or duplication and reduction of the dental germ, respectively. Dental formula in Otaria byronia shows a high degree of variability and this variability must be considered in the light of their phylogenetic relationships and their evolutionary history. The ecological approach suggests that dental anomalies do not affect longevity, and are unrelated to dietary items or environmental disturbances, but these points need more careful studies.

Resumo - Foram analisadas 63 anomalias dentárias em 62 espécimes de uma amostra total de 516 indivíduos da população Atlântica do leão marinho sul-americano Otaria byronia de Blainville, 1820. As anomalias foram representadas por 53 casos de pós-caninos 6 (segundos molares) ausentes, sete casos de dentes extranumerários maxilares/mandibulares, dois casos de dentes geminados, e um caso de dente reduzido. Considerando um contexto filogenético onde são incluídas todas as espécies de otarídeos e também Pinnipedimorpha basais, a ausência do pós-canino 6 pode estar relacionada às tendências evolutivas de redução e perda desse dente (agênese). A ocorrência dos sextos pós-caninos superiores em Otaria Perón, 1816 e em Phocarctos Peters, 1866 é, usualmente, considerada um caráter primitivo. Alternativamente, adotando-se um procedimento cladístico distinto, isto poderia ser interpretado como um atavismo táxico na base do clado Otaria/Phocarctos. Dentes extranumerários mandibulares são considerados casos concretos de atavismos espontâneos na dentição de Otaria byronia, em retrogressão a grupos ancestrais como o pinipedimorfo do Mioceno Pteronarctos Barnes, 1989. As outras anomalias - dente extranumerário maxilar, dente geminado e dente reduzido - são causadas por algum distúrbio no sistema epigenético subjacente à morfogênese dentária levando à duplicação, coalescência ou duplicação e redução do germe dentário, respectivamente. A fórmula dentária em Otaria byronia exibe um alto grau de variabilidade e essa pode ser compreendida à luz de suas relações filogenéticas e história evolutiva. Uma abordagem ecológica sugere que as anomalias dentárias não afetam a longevidade, e não estão relacionadas com itens da dieta ou a distúrbios ambientais, embora esses pontos mereçam uma análise mais aprofundada.
\end{abstract}

Keywords: agenesis, spontaneous and taxic atavisms, dentes geminati, extra teeth.

\section{Introduction}

Otaria byronia de Blainville, 1820 is a widespread otariid species along the South American coastline. On the Atlantic side it occurs from Torres, Brazil $\left(29^{\circ} 19^{\prime} S\right.$;

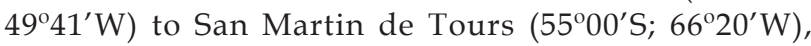
Argentina in southernmost South America, including the Malvinas Islands (Vaz-Ferreira, 1982) (Figure 1). Vagrant individuals are reported to reach Rio de Janeiro, Brazil $\left(23^{\circ} \mathrm{S}\right)$ (Vaz-Ferreira, 1981). In the Pacific side it is found from southern Chile to Zorritos $\left(4^{\circ} \mathrm{S}\right)$, Peru. Additionally, there are records of its presence in the Galapagos Islands (Wellington and de Vries, 1976), Colombia (Mora-Pinto and Muñoz-Hincapie, 1995) and Panama (Mendez and Rodriguez, 1984).

Dental anomalies are largely documented and studied in almost all mammalian orders (Wolsan, 1984), including variations in number (extra teeth, missing teeth), morphology (twin and reduced teeth, simplified patterns), position (displaced teeth) and occlusion, in eruption, or in the structure of teeth (colour changes, hypomineralization or hypoplasia of the enamel) (Hoff and Hoff, 1996). Dental anomalies can be related to genetic mechanisms, nutritional and metabolic diseases, and can provide clues to phylogenetic relationships and evolutionary trends.

Studies including dental anomalies in otariid species are rare. Drehmer and Ferigolo (1996) presented some anomalies for two Arctocephalus G. Saint-Hilaire \& Cuvier, 1826 species occurring in southern Brazil. Since no previous data exist, it is the goal of this study to quantify dental anomalies in Otaria byronia. We shall discuss all anomalies found, considering evolutionary implications, a

\footnotetext{
${ }^{1}$ Universidade Federal de Pelotas. Campus Universitário s/nº IB/DZG. Caixa Postal 354, Pelotas, RS 96010-900 Brazil. cjaeger@terra.com.br.

${ }^{2}$ Universidade Federal do Rio Grande do Sul (UFRGS), Programa de Pós-Graduação em Biologia Animal. Avenida Bento Gonçalves, 9500, Bloco IV, Prédio 43435, Sala 123, Porto Alegre, RS 91540-000 Brazil.

${ }^{3}$ Universidade Federal do Rio Grande do Sul (UFRGS), Departamento de Zoologia. Avenida Bento Gonçalves, 9500, Bloco IV, Prédio 43435, Sala 123, Porto Alegre, RS 91540-000 Brazil.
} 
phylogenetic framework and the evolutionary trends proposed for otariids. We shall also comment on the ecological significance for such anomalies in light of our knowledge about diet, behaviour, diseases and environmental disturbances for this species.

\section{Material and Methods}

A total of 516 specimens of $O$. byronia were analyzed from the following institutions: Museu de Ciências Naturais da Fundação Zoobotânica do Rio Grande do Sul, Brasil (MCN - 36 specimens); Facultad de Ciencias/Universidad de la República, Uruguay (ZVCM - 20 specimens); Museo Nacional de História Natural, Uruguay (MNHN-M - 2 specimens); Museo Argentino de Ciencias Naturales Bernardino Rivadavia, Argentina (MACN-Ma - 39 specimens); Centro Nacional Patagónico, Argentina (CENPAT - 419 specimens). This sample represents most of the Atlantic population of O. byronia in South America, over most of its continental distribution, with the exception of the Malvinas Islands (Figure 1). The osteological material obtained from this sample $(\mathrm{n}=516)$ is diverse, and was comprised of 361 complete skulls (syncranium), 86 incomplete skulls (no mandibles), seven skulls with just one mandible, 48 isolated mandibles, 12 mandible pairs and two isolated maxillaries. For the present study, complete skulls were defined as those possessing dental bones (premaxillaries, maxillaries and mandibles) even when some other cranial parts (such as the braincase), were missing. The total sample for analysis of upper and lower dentition was 456 and 428 specimens, respectively. Sex and age classes were obtained from data of the respective collections or measured/obtained directly from the specimen. Sex determination was based on the extreme sexual dimorphism, typical for all otariid species, especially on the development of the skull as a whole. Thus, for adult sea lions the presence of well developed sagital and nuchal crests, distinct mastoid processes, thicker zygomatic arch, distinct supraorbital processes and larger canine teeth are typical of the males. The size of the canine tooth was used to determine the sex of subadults and juveniles (Crespo, 1984). Only few specimens had absolute age estimates measured from dentin GLG counts. Therefore we have adopted age classes which were based on individual condylo-basal length (Cruwys and Friday, 1995), combined to age estimates according to the sutural-age method (Sivertsen, 1954), for both males and females. In the case of mandibular specimens we made a direct comparison to the ones having complete skulls to estimate the age class. The total numbers are: 159 juveniles, 82 subadults, 266 adults and 9 unknown (too fragmentary for dating); 285 males, 207 females and 24 unknown (too young for precise dating). The terms adult, subadult and juvenile refer to bone maturity and have distinct connotation regarding their ecological significance.

Dental losses due to traumatic events, evidenced by closed (or in process of closure) alveoli, and very common in otariid species, are not included in this analysis (Figures 4, 11).

The systematics adopted here follows Berta and Deméré

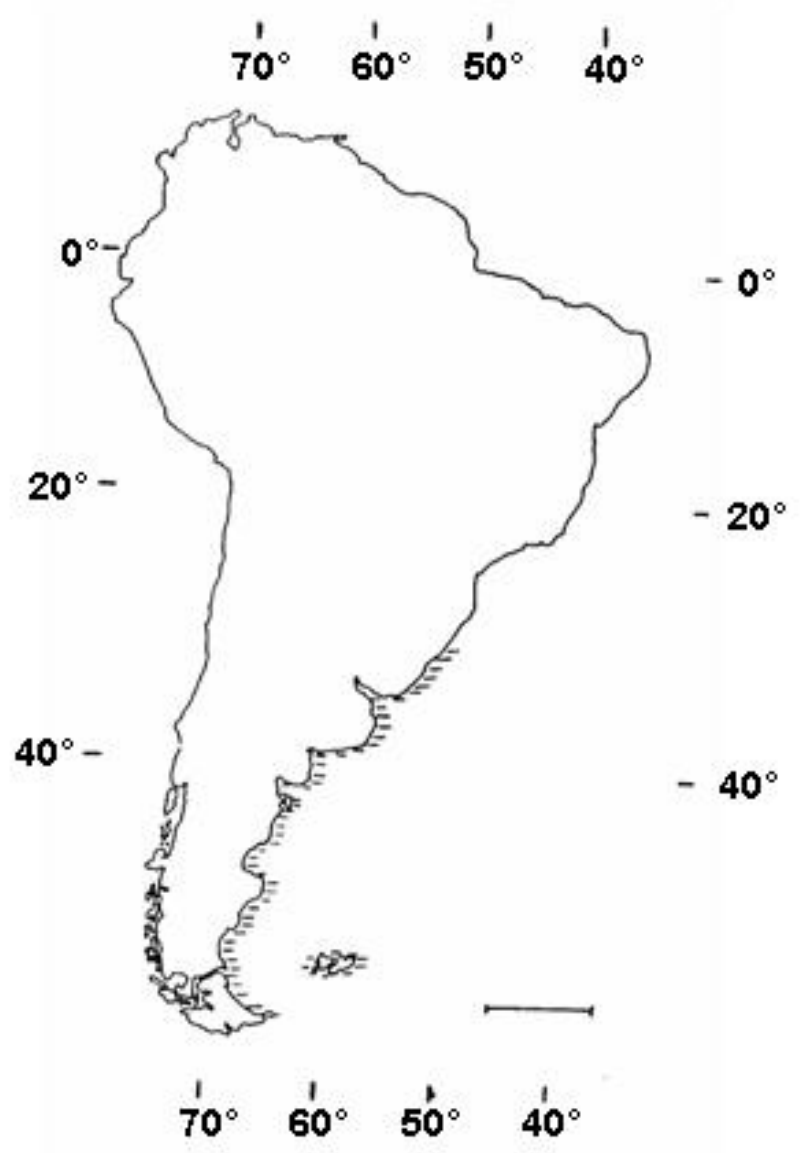

Figure 1. Map of South America showing the Atlantic distribution of Otaria byronia. Scale bar $=1000 \mathrm{~km}$.

(1986), Berta and Wyss (1994) and Tedford et al. (1994). The long disputed specific epithet for this species is based on Gardner and Robbins (1999, case 3058) who argued for Otaria byronia, on the grounds of the International Commission of Zoological Nomenclature (Commission of Zoological Nomenclature, 2000).

Dentition in pinnipeds has been simplified in shape and reduced in size (Berta and Sumich, 1999). Miyazaki (2002) reported that in otariids deciduous dentition is shed between 4-5 months of life. Indeed, all specimens studied here have the permanent dentition or, at least, their respective alveoli. Some very young specimens have emerging permanent teeth, retaining upper and/or lower deciduous canines, which are the last ones to be lost in Otaria byronia.

The conventional and useful term "post-canine" for pinniped dentition is here reported, but the terms "pre-molar" and "molar" are also used, based on Barnes, 1989. The dental formula for Otaria byronia is I3/2, C1/1, PM4/4, M2/1.

Data from anomalous specimens are in Appendix 1.

\section{Results}

All anomalies found were in the post-canine dentition and are related to number or morphology. They represented 63 cases in 62 specimens $(12.02 \%, n=516)(Z V C M 28$ has 
two kinds of anomalies). We classified them in five categories: lower extra teeth, upper extra teeth, dental agenesis, twin teeth (dentes geminati) and reduced teeth.

Lower extra teeth: They occurred in four specimens: MACNMa 21738, CENPAT 437, CENPAT 199 and CENPAT 491 $(0.93 \%, n=428)$. In all four specimens the extra teeth occurred on both sides at the position M2 leading to a general dental formula of: I3/2, C1/1, PM4/4, M2/2 x 2. In MACN-Ma 21738 (Figure 2) there are no teeth, but the alveoli indicate their former presence. CENPAT 437 represented a very young specimen, with lower and upper canine milk teeth and both second molars still emerging (Figure 3). Specimen CENPAT 199 (Figure 4) had both second molars reduced in size, with strong wear at the crowns and no cingulum. The roots were single and heavily cemented (Figure 5). Specimen CENPAT 491 (Figure 6) had only the right M2 present, which was reduced, with a broken crown and a single root (Figure 7). The root was less cemented than that of specimen CENPAT 199.

Upper extra teeth: In three specimens they occurred in different ways $(0.66 \% \mathrm{n}=456)$. MACN-Ma 21743 exhibited extra teeth on both sides but in different positions: On the right side the teeth were displaced externally between PM2 and PM3, while on the left side they were displaced externally between PM3 and PM4 (Figure 8). Both teeth were reduced, with a single root, discrete cingulum and an anterior accessory cusp. The right tooth seemed to be a little more developed in size than the left one (Figure 9). CENPAT 515 exhibited an extra tooth (right side) located between PM2 and PM3 (Figure 10). This tooth had a well developed crown with cingulum and a conspicuous accessory anterior cusp, but no posterior one. This specimen differed from the others in having the extra tooth aligned in the tooth row, showing a discrete displacement counter-clockwise. CENPAT 157 $\underline{\underline{2}}$

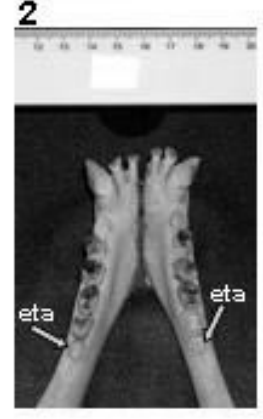

6

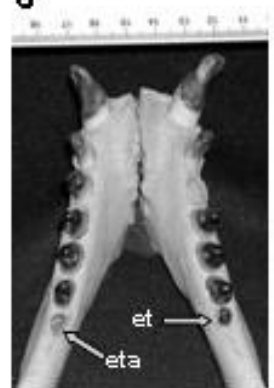

3

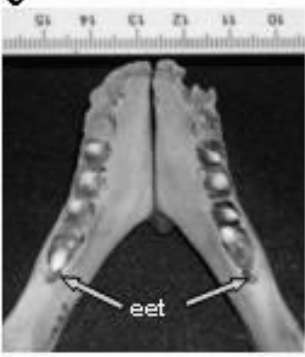

7

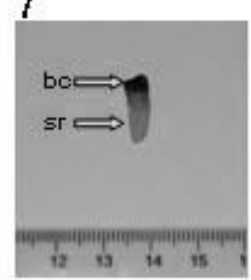

10

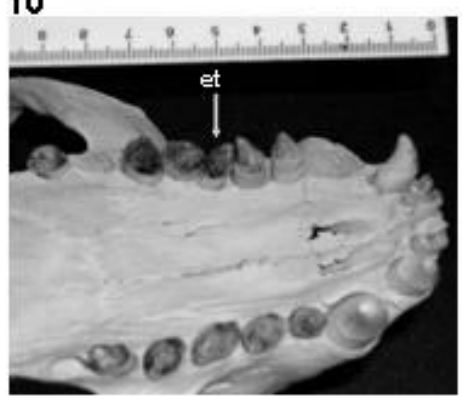

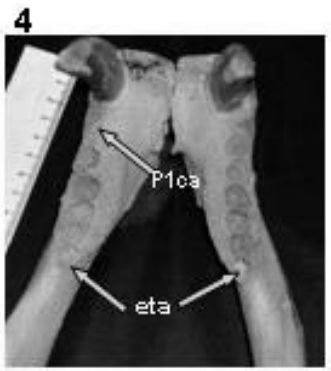

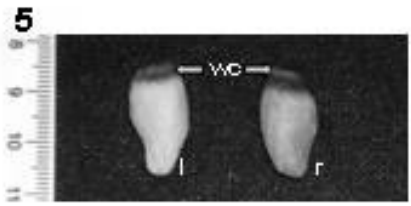

8

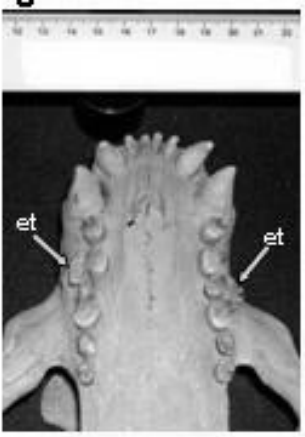

11
9

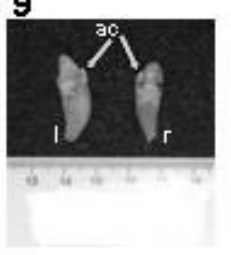

Figures 2-11: fig.2. MACN-Ma 21738 showing extra teeth alveoli (eta) on both mandibles; fig.3. CENPAT 437 showing emerging extra teeth (eet) on both mandibles; fig.4. CENPAT 199 showing extra teeth alveoli (eta). Note the pathological absence of left P1 and its closed alveolus (P1ca); fig.5. CENPAT 199. Left (l) and right (r) extra teeth in lingual (or labial) side. Note the weared crowns (wc); fig.6. CENPAT 491. Extra right tooth (et) and extra left tooth alveolus (eta); fig.7. CENPAT 491. Right extra tooth in lingual view. (bc - broken crown; sr - single root); fig.8. MACN-Ma 21743 showing both upper extra teeth (et); fig.9. MACN-Ma 21743 showing isolated upper extra teeth, left (l) and right (r), in lingual (internal) side. Note the reduced accessory anterior cusps (ac); fig.10. CENPAT 515 showing upper right extra tooth (et). Note its aligned position in the tooth row; fig.11. CENPAT 157 showing upper right extra tooth (et). Note the remains of M1 and M2 alveoli (M1ar, M2ar, respectively). All scales in centimeters. 
exhibited the extra tooth at the right side and was displaced internally (lingual side) between PM2 and PM3 (Figure 11). This specimen was a very old male with all post-canine dentition showing strong occlusal wear (no cusps and no cingulum). Additionally, the right M1 and M2 teeth were traumatically lost with only traces remaining in their alveoli (Figure 11). Regarding the upper incisors, both upper I3 were broken, and I1 and I2 were lost on both sides, with the alveolar area (pars incisiva) totally closed.

All upper extra teeth occurred in the pre-molar region leading to a general bilateral formula of I3/2, C1/1, PM $5 / 4, \mathrm{M} 2 / 1 \times 2$. When unilateral, the formula was $\mathrm{I} 3 / 2, \mathrm{C} 1 /$ 1, PM5/4, M2/1 for the anomalous side, and I3/2, C1/1, PM4/4, M2/1 for the normal side.

Dental agenesis: All observed dental agenesis occurred at the upper second molar position, bi- or unilateral. This was the most frequent anomaly in this study, occurring in 53 specimens $(11.62 \%, \mathrm{n}=456)$. It was characterised by no trace of one or both second molar(s) or its (their) alveolus (alveoli). Thirty two cases were bilateral (Figures 12, 15, 16), nine were on the left side (Figure 13), and 10 were on the right side (Figure 14). Two additional specimens had missing left M2s, but since they had incomplete skulls we were unable to confirm the bilaterality. Bilateral dental agenesis may occur in juveniles $(18 / 53=33.96 \%$; Figure $15)$, subadults $(9 / 53=16.98 \%$; Figure 12$)$ or adults $(26 / 53$ $=49.06 \%$; Figures 13, 14, 16). It may also occur in females $(13 / 53=24.53 \%$; Figure 16$)$ and males $(39 / 53=73.58 \%$; Figures 12-15), and it was present in one young specimen (CENPAT 220) for which there was no determination of sex $-1.89 \%$ ). All these records of missing second molar (s) exclude traumatic losses, something very frequent in this species, particularly in adult males (Figures 4,11). No mandibular dental agenesis was found in our sample.

Dentes geminati: Given that many specimens had no teeth on their skulls, we were unable to confirm the occurrence of dentes geminati since the alveoli by itself provide insufficient evidence. ZVCM 28 and CENPAT 115 exhibited dentes geminati. In the former, an adult male, this anomaly occurred on the right mandible, uniting PM4 and M1 by their root and the base of the crown, while the top of the crowns remained free (Figure 17). CENPAT 115, a very young male, exhibited double upper PM3 teeth in both sides (Figure 18). The roots, as well as the crown basis were open and fused. On the left side, the double crown had a small unfused portion $(2.3 \mathrm{~mm})$ and on the right side, the unfused area measured approximately $4.0 \mathrm{~mm}$ (Figure 19). There was a small external and internal groove in the root as well as an accessory anterior cusp in the anterior twin, and an accessory posterior cusp in the posterior twin.

Reduced teeth: This anomaly occurred just in one specimen $(0.19 \%, n=516)$. CENPAT 301, a juvenile male, exhibited a very small circular alveolus $(2.9 \mathrm{~mm}$ length, $2.7 \mathrm{~mm}$ width and $2.5 \mathrm{~mm}$ deep) in position PM4 at the upper right side (Figure 20). Unfortunately, there no tooth was present. Judging from the size of the alveolus the tooth was very small, and probably very reduced, resembling a deciduous peg-like pre-molar.

\section{Discussion and Conclusions}

Extra mandibular teeth: Pinniped origins are long disputed. Since the middle XIX century the controversy over pinniped monophyly or diphyly has produced an intense debate in different biological areas (paleontology, morphology and molecular biology), and no consensus was attained. We favor a monophyletic vision, based on Berta and Wyss (1994), who argued consistently for a single origin of Pinnipedia among the Arctoidean Carnivora, based on morphological and paleontological data, rejecting the hypothesis of convergence (Wozencraft, 1989). In this context, otariids would be basal pinnipeds, with Pteronarctos (an early Miocene pinnipediform) as a sister-taxon.

The description shows that in all four specimens, the extra mandibular teeth corresponds to the lower second molar. Little differences, such as the pattern of cement deposition from individuals CENPAT 491 and 199 were likely due to sexual dimorphism, since male (the latter) post-canine roots tend to be more cemented than those of females. Their position and alveolar morphology (indicating a reduced, single cusped and weak tooth cingulum) are the same found in Pteronarctos and also in Enaliarctos (Mitchell and Tedford, 1977) -a late Oligocene-early Miocene pinnipedimorph. The absence of a second lower molar is "a potential synapomorphy" for diagnosing Pinnipedia (Berta and Wyss, 1994, character 73, page 40), thus its presence in these four specimens could be attributed to a case of spontaneous atavism. Hall (1984: p.89) proposed four criteria to define atavism:

- persistence into adult life;

- absence in the parents or recent ancestors;

- presence in only one or a few individuals within a population; and,

- close resemblance to the same character possessed by all members of an ancestral population.

Clearly, the third criterion is completely fulfilled, since just four specimens present the lower second molar (MACN-Ma 21738, CENPAT 199, 491 and 437; representing $0.77 \%$ of the whole sample). Excluding CENPAT 437 (a very young specimen with lower and upper canine milk teeth still present), the remaining three specimens were adults, thus meeting the first criterion. King (1964, plate 13) presented an X-ray of the left mandible of a young Otaria byronia, showing permanent and characteristic peg-like milk teeth. Interestingly, in the permanent post-canine dentition there are six teeth, the last one being the M2. In fact, we can not sustain that in this specimen - as for specimen CENPAT 437 - the emerging M2 teeth would persist into adult life. Thus, these are in fact suspected cases of spontaneous atavisms, but no confirmation is possible. According to Hall (2003), these teeth would be regarded as "rudiments" since they are only expressed in the early stages of development. 
Since no recent or fossil otariid genera have the lower second molar, the absence of this tooth fulfills the second criterion (Figure 21). The most primitive known otariid, Pithanotaria starii Kellog, 1925 (late-middle Miocene) could have had the second lower molar, but the dental formula presented by Repenning and Tedford (1977) is conservative, given that no complete mandibles were found.

Generally no population data is available on fossil vertebrate species. Even though the information regarding fossils is scarce, both Pteronarctos and Enaliarctos have enough mandibular material to confirm the presence of the lower second molar. Berta (1994) presented new specimens for the former and thus increased the credibility of some diagnostic characters: specimen USNM 335432 and USNM 167648 showed the second molar alveolus (Figure 8, page 12; Figure 15, page 19). Although the tooth was absent, the alveolar morphology indicated its presence and given the size of the tooth it was reduced, single rooted and, probably, single cusped. In the following, we compared our data to
Enaliarctos; although this genus has been treated as a metataxon (Berta, 1994). For three recognized species (E. emlongi Berta, 1991, E. tedfordi Berta, 1991 and E. mitchelli Barnes, 1979) the alveolar morphology of lower second molar corresponded to the same description referred to for Pteronarctos, meeting the fourth criterion. Two other species (E. barnesi Berta, 1991 and E. mealsi Mitchell and Tedford, 1973) had no associated mandibles.

Atavistic teeth were reported for other carnivore groups: The upper dentition in Eurasian badger Meles meles (Linnaeus, 1758) (Hancox, 1988) and the lower dentition in the European lynx Lynx lynx (Linnaeus, 1758) (Kvam, 1985; Wederlin, 1987). Spontaneous atavisms in structures other than teeth have been proposed in the vertebrate literature. They include classical examples like horse digits (Hall, 1984), cetacean hindlimbs (Bejder and Hall, 2002), passeriforme muscles (Raikow, 1975), and more examples in the medical literature (Arey, 1954 in Hall, 1984). In fact, they are probably more common than the scientific literature reports (Riedl, 1977).

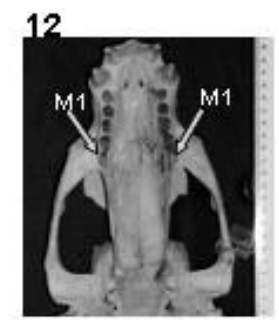

15

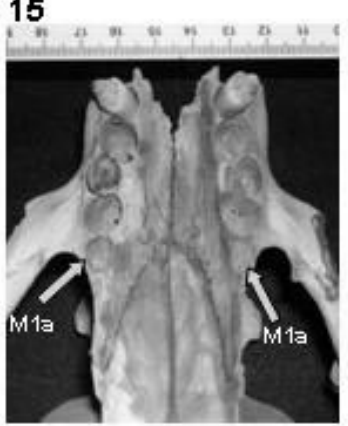

18

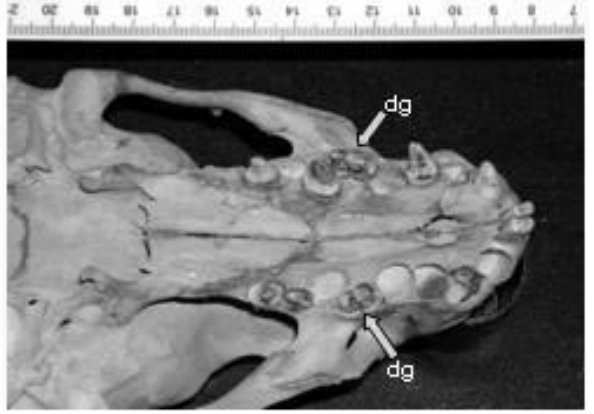

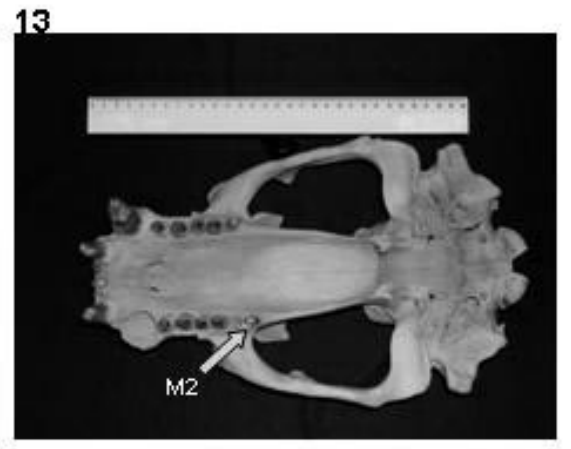

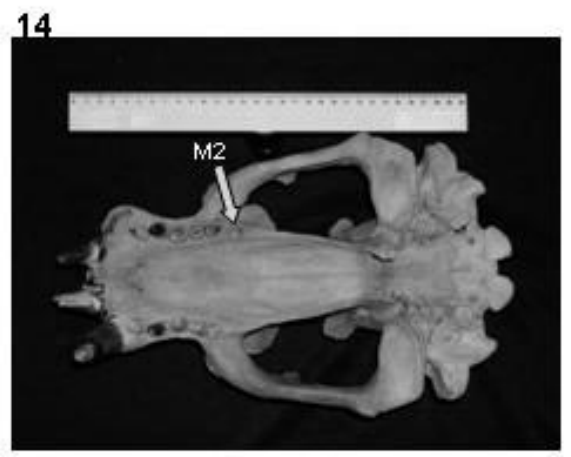

16

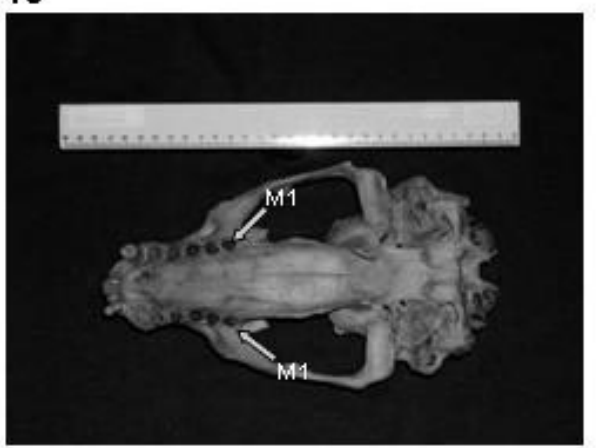

17

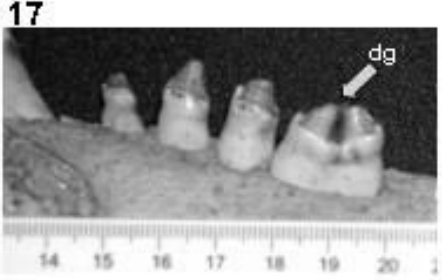

20

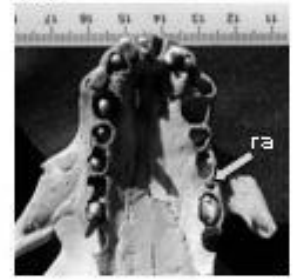

Figures 12-20: fig.12. CENPAT 457, a subadult individual showing both M1 and missing upper M2; fig.13. CENPAT 531. An adult individual showing missing upper left M2; fig.14. CENPAT 424. An adult individual showing missing upper right M2; fig.15. CENPAT 36, a juvenile individual showing both M1 alveoli (M1a) and missing M2 (note the absent pre-maxillaries by natural disarticulation); fig.16. CENPAT 178. An adult female showing both M1 and missing M2; fig.17. ZVCM 28, showing dentes geminati (dg) on right mandible; fig.18. CENPAT 115, showing dentes geminati $(\mathrm{dg})$ on both maxillaries; fig.19. CENPAT 115. Both dentes geminati (l, left; $r$, right) in lingual view, showing double crown (dc) and opened double root (odr); fig.20. CENPAT 301, showing the reduced tooth alveolus (ra). All scales in centimeters. 


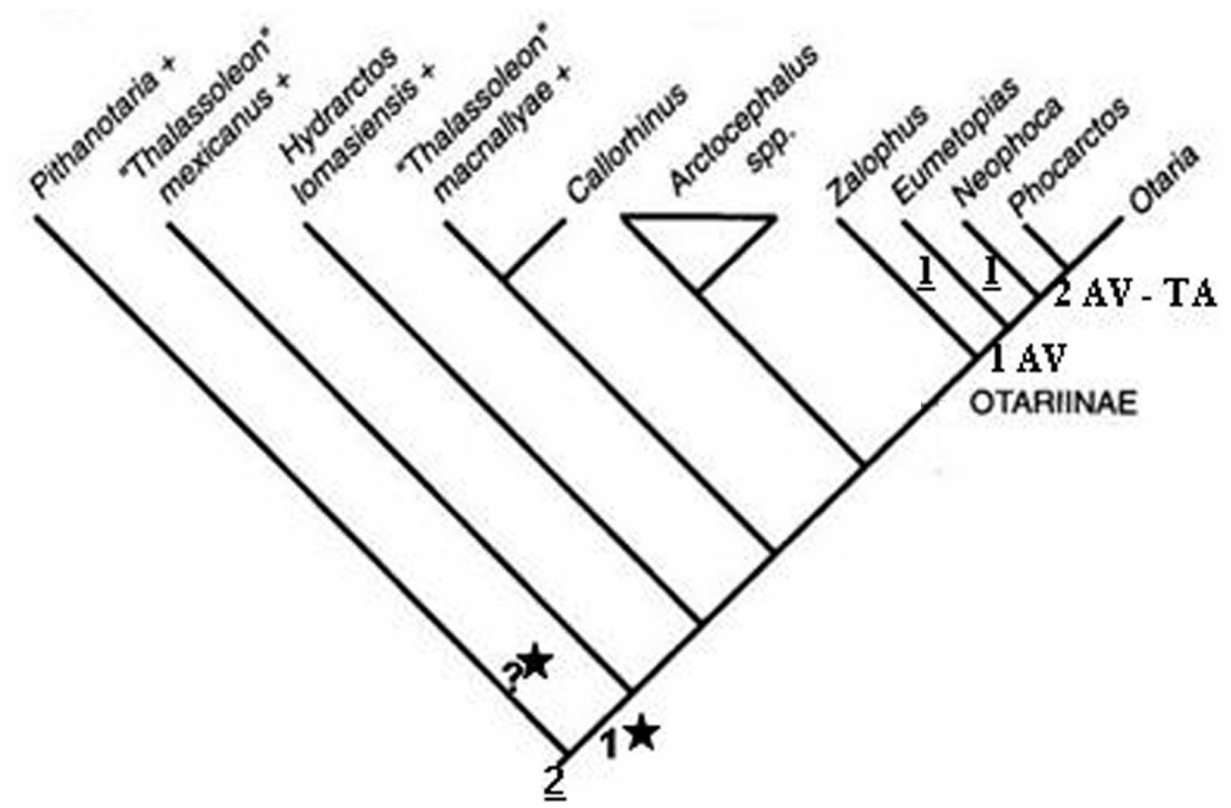

Figure 21. Phylogenetic relationships in Otariidae, showing the number of lower molars (1) in all, but Pithanotaria (black stars); the number of upper molars showing the primitive (2) and derived condition (1) acquired independently in Neophoca and Eumetopias (underlined); the number of upper molars showing the primitive (2 underlined) and derived (1) condition in alternative view (AV) to the lost of M2 involving a taxic atavism (TA) in Phocarctos/Otaria clade. From Berta \& Deméré, 1986.

Changes in the genetic network that regulates morphogenesis have been related to macroevolutionary events in mammals, and these variations could be responsible for their diversification (Line, 2003). Particularly in the case of atavisms, Line's (2003) statement could be plausible, since spontaneous atavisms have been related to macroevolutionary events (Riedl, 1977).

Drehmer and Ferigolo (1996) described extra-mandibular teeth in the otariid species Arctocephalus tropicalis (Gray, 1872), the subantarctic fur seal. These extra teeth were found on both sides, internally positioned between the lower PM3 and PM4. Judging by its position on the tooth row this anomaly can not be regarded as an atavism, differing from the situation described for Otaria byronia. The extreme resemblance of the lower second molar found in Otaria byronia to the ancient Pteronarctos or Enaliarctos shows a gap of about 15-20 million years regarding the potential formation of lower second molars, indicating that this atavism is a setback prior to the divergence of the Pteronarctos/Pinnipedia (Figure 22). Marshall et al. (1994) considered an evolutionary reversal over 10 million years almost impossible, unless the genes and developmental pathways of the formation of the atavistic structure were linked to other pathways in the development. Quoting the authors discussing the classical example of Lynx Kerr, 1792 of lower second molars reappearance: "suppression of M2 probably did not involve the loss of any structural genes, since the same genes are presumably required for the morphogenesis of all teeth" (Marshall et al., 1994:12287). Recently a high number of homeobox genes related to the regulation of tooth morphogenesis have been identified (e.g., sonic hedgehog, Dassule et al., 2000). Their analyses suggest a highly conserved pathway for tooth regulation during vertebrate evolution (Thesleff, 2000).
Lande (1978) demonstrates that limblessness in some groups of tetrapods is polygene-regulated and the genes involved have pleiotropic effects. The sporadic occurrence of hindlimbs in cetaceans (Andrews, 1921) is possible since genes acting on hindlimb development are also associated with the development of quite different structures such as jaws, teeth and genitalia (Bejder and Hall, 2002). Thus we suggest that there is the maintenance of genetic and developmental pathways to the formation of lower second molars in Otaria byronia in a "quiescent way". This is possibly an inactive but not lost genetic and developmental information, available for expression under unknown stimulus, but presumably related to interactions between the organism and the environment during ontogeny, a source for phenotypic variation as predicted by the epigenetic approach to evolution proposed by Waddington (1975).

Another proposed phylogeny for otariids is based on cytochrome-b sequences (Wynen et al., 2001) and does not include fossil taxa, thus being inappropriate to our purposes. Quoting the authors (op. cit., p.282): "the inference of phylogenetic relationships on the basis of a single locus is to be regarded with caution".

Upper M2 agenesis: The natural absence of six or less teeth in mammals is referred to as hypodontia (Hoff and Hoff, 1996). The absence of one or both second molar(s) in 53 of the 456 studied specimens could be related to evolutionary trends in Otariidae. Vaz-Ferreira (1981) states that the last upper molar is "very often missing" in Otaria byronia, but he did not give more details. Chiasson (1957) regarded the sixth upper post-canine of the Northern fur seal Callorhinus ursinus (Linnaeus, 1758) as a vestigial structure and its progressive loss could be considered a specialization in the 


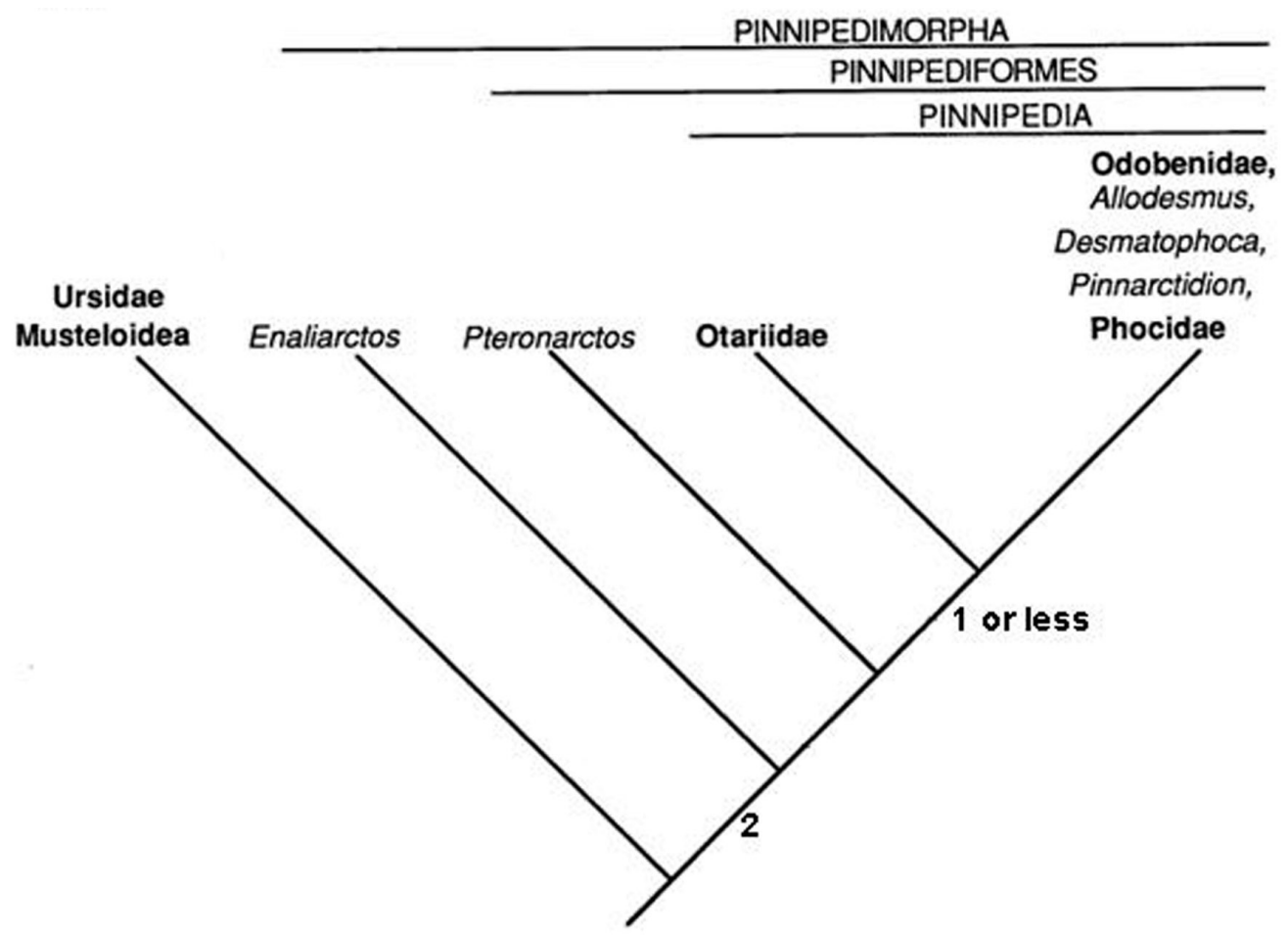

Figure 22. Phylogentic relationships among Pinnipedimorpha, showing the number of lower molars in Pinnipedia (1 or less) and in Pteronarctos and Enaliarctos (2). From Berta \& Wyss, 1994.

evolution of the species. Barnes (1989: p.11) argued for otariids that "progressive evolutionary loss of the [upper] M2 through time in some lineages has produced the more derived condition of five upper cheek teeth". In the five known recent genera of Otariinae (sensu Berta and Deméré, 1986) there is a variable number of upper post-canines. King (1964) reported for Zalophus californianus (Lesson, 1828) that Californian animals have five upper post-canine teeth, the Galapagos population have six, and the probably extinct Japanese population exhibit variable numbers of five or six PC. These groups have been recently treated as distinct species (Heath, 2002), even though this systematic vision needs more detailed studies. Eumetopias Gill, 1866 (Steller sea lion) and Neophoca Gray, 1866 (Australian sea lion) have just five upper post-canine while Phocarctos (New Zealand sea lion) and Otaria have six. Berta and Deméré (1986) consider the reduction in number of upper post-canine from six to five a derived feature for Otariidae, acquired independently (a homoplasy) in Eumetopias and Neophoca (Figure 21). Alternatively, and with no loss of parsimony in the authors final cladogram (Berta and Deméré, 1986: Figure 7) the upper second molars could be lost at the basal node of the Otaria/Phocarctos/Eumetopias/Neophoca clade and reverted at the level of the Otaria/Phocarctos clade (Figure 21). This hypothesis could be supported by the same kind of evolutionary phenomenon attributed to lower M2: the atavism. In this specific case not a spontaneous but a taxic atavism with the reversion to the ancestral state of two upper molars is being postulated for Otaria/ Phocarctos clade. Taxic and spontaneous atavisms are manifestations of the same kind of phenomena (Stiassny, 1992) and are being increasingly suggested for several groups (Stiassny, 1992 for cichlid fishes; Raikow et al., 1979 for some passeriforms; Gatesy et al., 2003, for gavialine crocodilians). In Pinnipedia a broad and massive pattern of retrogressive events driving the evolution of phocine seals (Wyss, 1988) was proposed. The relatively high (53/516) frequency of absent upper second molars (at least in one side) corroborates this hypothesis. This frequency is higher in magnitude when compared to other mammal species (for example, Hoff and Hoff, 1996 quoted western populations of Mus musculus (Linnaeus, 1758) showing $0.63 \%$ agenesis, usually the lower third molar, and Eurasian populations showing little higher frequencies $-3.38 \%$ ). These differences suggest that there is some genetic/developmental instability (Kubota and Togawa, 1964) in the formation of this tooth among part of the Atlantic population of Otaria byronia (like the one referred to Zalophus californianus populations) leading to the normal agenesis of this tooth.

No adaptation must be postulated, since pinnipeds in general do not slice or chew the prey, and use teeth just to grip slippery prey (Berta and Sumich, 1999). Thus, any adaptive advantage in having one or two upper molar(s) is unlikely. We regard this variation in Otaria byronia as a result of a fluctuating occurrence of the upper second molar as a consequence of natural dental agenesis, without any influence in an increasing/decreasing ability to grip the prey. Natural agenesis not related to any syndrome and associated to homeobox genes, is largely studied in humans (Gorlin et al., 2001) where the absence of third molar is the 
most common. In fact, in a tooth row that one positioned at the ends are more liable to loss and especially among molars the last one (Adam, 20014). Wolsan (1984: p.129) states that "the progressive simplification in shape and simultaneous reduction in size of a tooth have clearly preceded its loss", although pinniped dentition is naturally simplified and reduced when compared to fissiped carnivores. This statement seems to be true for Otaria byronia's upper second molars, a naturally reduced and simplified tooth in comparison to the other five upper postcanines. Likewise, it is difficult to postulate for the "lack of function" of these teeth (upper M2) because it requires an extensive knowledge of the feeding mechanisms and its biomechanical implications for this species. Hall (2003) says "assessing lack of function, as with assessing adaptation, is always difficult, and one needs a thorough, if not total, knowledge of the biology of the organism".

Hoff and Hoff (1996) state that subnumerary teeth (due to agenesis) are not as common as supernumerary, what is in disagreement with our study. For Otaria byronia, at least, the most frequent anomaly that we have found is the lack of the upper second molar (83.82\% of the reported cases).

Dentes geminati: Hoff and Hoff (1996: p.103) defined dentes geminati (double or twin) as "two or more parts that clearly demonstrate a tendency towards independence". Feldhamer and Stober (1993) named them as "fused". This is the case for right mandible of ZVCM 28 and for both maxillaries of CENPAT 115. Judging from the description presented above, we suggest that for the first specimen the dentes geminati arose from the coalescence of two regular dental germs (lower PM4 and M1) probably at an early phase of the development since no extra teeth exist. The second specimen exhibited the dental germ of the upper PM3 teeth split (duplication) to form the dentes geminati on both sides. Kubota and Togawa (1964) reported this kind of dental anomaly in Callorhinus ursinus (the northern fur seal), although their specimen presented geminati on the right maxilla and extra teeth on the left, suggesting a complete division of the dental germ from PM2 at one side (left) and partial division of the corresponding tooth on the right side (Kubota and Togawa, 1964, plates 8, 9, 10). Indeed those examples suggest that geminati can be a developmental precursor for extra maxillary teeth.

Extra maxillary teeth: A phylogenetic analysis of the pinnipeds reveals that no recent or fossil genera have more than six upper post-canine teeth (four pre-molars and two molars) (Berta and Wyss, 1994). The same is true for Pteronarctos and Enaliarctos. If we go back in the phylogeny (proposed by Tedford et al., 1994) we will see that Pinnipedimorpha (the wider group which includes Pinnipedia) is closely related to Ursoidea, a taxon that includes the traditional family Ursidae and four genera of Tertiary carnivores - Amphicynodon Filhol, 1882, Pachycynodon Schlosser, 1887, Allocyon Merriam, 1930 and Kolponomos Stirton, 1960 (Figure 23). None of them have more than two upper molars (Tedford et al., 1994, character 3, page 29 - upper M3 absent units all arctoids above Amphicyonidae). Following back in the cladogram we will find the Mustelida (a taxon including Mustelidae and Procyonidae) a group where no more than two upper molars are present. The description of the four specimens showing upper extra teeth indicates that none is positioned at the end of the tooth row. That is, all teeth arise at the pre-molar area. Looking at the phyletic comparisons and at the position of the teeth along the tooth row, there is no support for the atavistic hypothesis, since no Pinnipedimorpha, Ursoidea or Mustelida have more than four pre-molars and two molars (Figure 23).

Hoff and Hoff (1996: p.101) defined a super-numerate tooth as an excess of normal deciduous or permanent dentition, imitating or not the shape of normal teeth. They proposed local driving factors such as inflammation, scarring, abnormal pressure and disturbed relationships between cells that are potentially either organizers or receptors in odontogenesis as the probable causes for extra teeth. Wolsan (1984) proposed two possible mechanisms for the origin of extra teeth: one related to atavisms (though he did not use the term); and, another related to dental germ splitting due to mutations, disturbances or changes in the genetic control of tooth development (such as a homeobox gene, as previously discussed regarding extra mandibular teeth). Analyzing the three specimens that exhibited extra maxillary teeth we suggest that some kind of developmental disturbance have caused abnormal dental germ division, given that we reject the atavisms hypothesis for extra upper teeth as discussed above, and we favour Hoff and Hoff's "disturbed relationships" and Wolsan's "tooth germ splitting" hypotheses. Mutations, diet deficiencies and infections have been proposed as causes for dental germ splitting (Wolsan, 1984) but, unfortunately, we cannot entertain these explanations under the present work.

Although the identification of extra teeth is easy by comparison of tooth morphology, this cannot be said about their exact origin. In Otaria byronia, the pre-molar region is prone to the appearance of upper extra teeth, especially for PM2, 3 and 4, according to Hall (1940), who established that the pre-molar region in carnivores and insectivores is the commonest region for this kind of anomaly. Specimen MACN-Ma 21743 represented an interesting anomaly with the extra teeth located at different positions on the left and right side. It is not possible to decide which dental germ has been split (i.e. PM2, PM3 or PM4). Specimen CENPAT 515 also exhibited the same situation for the right side as did specimen MACN-Ma 21743. Nevertheless, the position of the extra tooth in the tooth row seemed to be closer to the general alignment, may be because this was a young specimen with a growing skull. Specimen CENPAT 157 clearly exhibited an extra tooth between PM2 and PM3, on the right side. This was an old individual and the extra tooth was positioned internally (medially).

${ }^{4}$ Adam, P.J. (2001) On Being "PC" with Seals: Dental Homologies in the Pinnipedimorpha. Page 2 in Abstracts of the $14^{\text {th }}$ Biennial Conference on the Biology of Marine Mammals, 28 November - 3 December, Vancouver, Canada. 


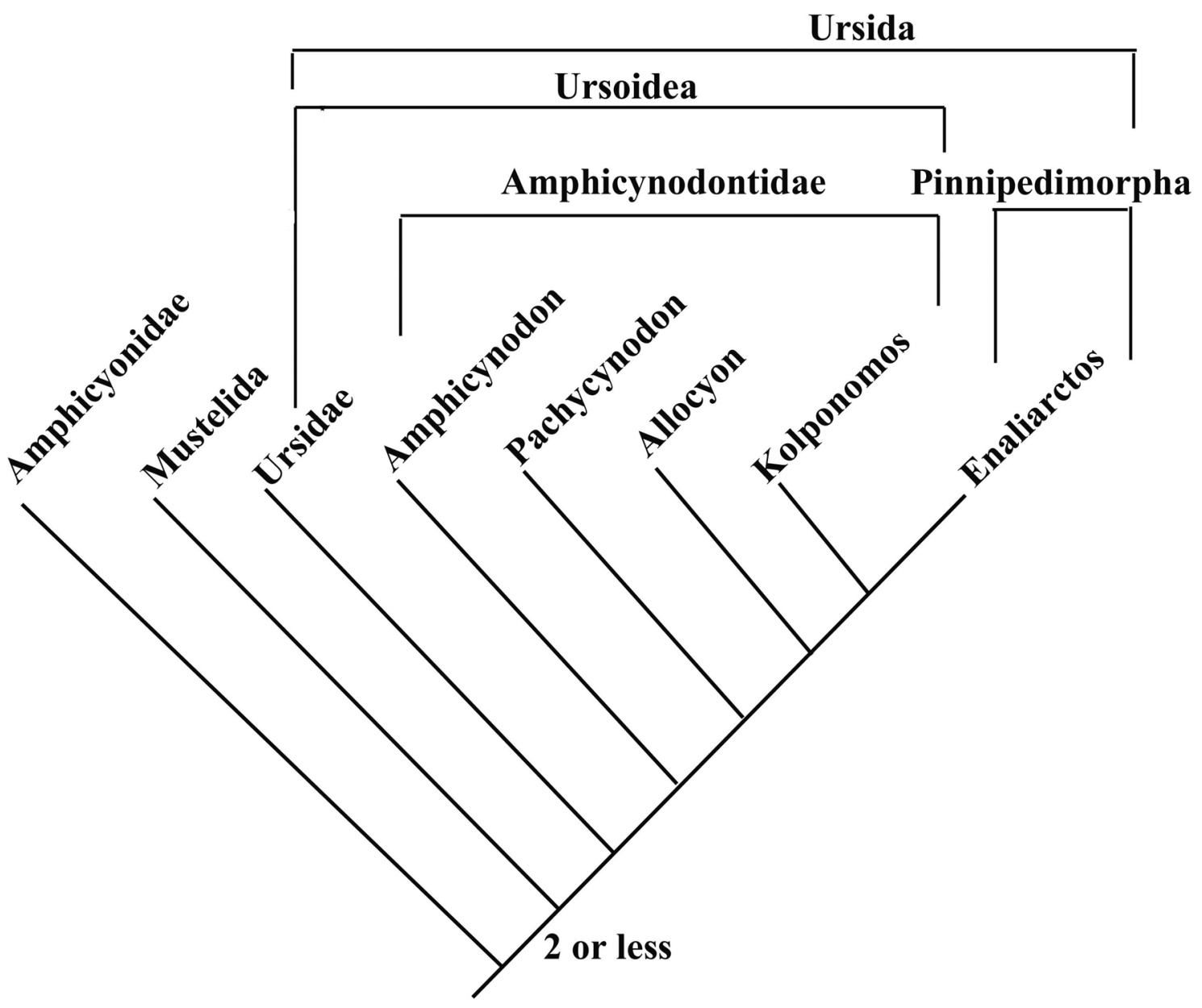

Figure 23. Phylogenetic relationships among Pinnipedimorpha and other Carnivora Arctoidea showing the conserved number of upper molars (2 or less) (see Tedford et al., 1994 for taxonomic ranking).

Reduced teeth: Reduced teeth have been described as "diminutive" in mammal populations (Feldhamer and Stober, 1993, for north American soricids). Specimen CENPAT 301 exhibited a reduced tooth at PM4 position but, unfortunately, the tooth was missing. Considering the size and the alveolar morphology, this tooth was reduced in size and peg-like (very simplified in form), so we can not reject the hypothesis that it represented a deciduous one that was maintained through permanent dentition. If this is true, there would be just five upper permanent post-canine teeth, even though the comparison of alveolar morphology between both tooth rows has indicated that PM1, 2 and 3, and M1 and 2 were present. This finding thus suggests that this tooth is likely to be a permanent PM4 which was reduced at its genesis (i.e., since dental germ stage) but with no correspondence on the left side. Dassule et al. (2000) reported a reduced tooth size by manipulation of the activity of gene sonic hedgehog in mouses, concluding that the action of this gene is essential for dental growth and morphogenesis. Thus, genetic disturbance could be the explanation for the reduced tooth found in Specimen CENPAT 301.
Ecological approach: Stewart and Stewart (1987) working with harp seal (Phoca groenlandica Erxleben, 1977) mandibular dental anomalies have rejected the possibility of using these anomalies for stock identification. Atlantic rookeries of Otaria byronia are likely (seem) to be part of the same population (Szapkievich et al., 1999). Consequently, we should not expect that specimens from colonies at the boundaries of the species distribution (northernmost and southernmost) would exhibit any difference in the frequency of anomalies found. Moreover, our sample is too heterogeneous to assess for local differences in anomaly frequency, because more than $70 \%$ of the total specimens came from southern Argentina (CENPAT specimens), where we find the major breeding areas for the Atlantic population (Vaz-Ferreira, 1982). A future study including Pacific populations (Chile and Peru) will provide data for comparison between populations of both sides of South America.

We applied chi-square tests corrected for continuity to verify statistically any possible significant differences in the incidence of dental anomalies among age classes (juvenile, subadult, adult) of Otaria byronia from Atlantic 
Ocean. Although the power of the tests has been lower than $10 \%$, all the results were similar: age categories do not affect the proportion of dental anomalies. The same conclusion was reached by Stewart and Stewart (1987) who analyzed a large sample $(n=1601)$ of Phoca groenlandica mandibles.

Based on this indication, we tested also for a possible significant difference of dental anomalies between males $(n=285)$ and females $(n=207)$ of Otaria byronia, regardless of the age. The result showed that frequency in dental anomalies is higher in males $(p=0.015)$.

Another point to take notice is the possibility of these anomalies being related to some environmental disturbance. Jimenéz et al. (1999) analyzed the level of concentration of dioxins in individuals from two Otaria byronia rookeries of Argentina. Individuals from the northern rookery (Mar del Plata) had higher concentrations than those from the southern one (Punta Bermeja) but both levels were low compared to other mammalian species. We have no evidence that these contaminants are related to dental anomalies but this is a very fruitful hypothesis for future research.

Despite of being out of the scope of this work, we present here a comment about pathologies. Pinnipeds in general and otariids in particular, are naturally exposed to traumatic dental loss and dental pathologies (Drehmer and Ferigolo, 1996; Erb et al., 1996; Drehmer et al., 1998) due to several factors probably related to aggressive behavior (Campagna et al., 1988; Vila and Cassini, 1990). Indeed, natural tooth wear is characteristic for this species - typical for the inner surface of lower canines due to occlusion with upper ones - been more critical in older individuals. Tooth wear is the natural way leading to any traumatic event because a tooth in this condition is more susceptible to fracture and subsequent loss, or by exposing pulp cavity in a way to get an infection. Another aspect of Otaria byronia's behavior is its ability of ingesting gastroliths. These rocks are swallowed intentionally [Mathisen et al., 1962 referring to Eumetopias jubatus (Schreber, 1776)] to be probably used as a ballast in buoyancy control (Koen Alonso et al., 2000 for Otaria byronia), thus, in some cases, could be the cause of a dental fracture, or dental avulsion, with remaining traces of the tooth or alveolus. In general, we think that diet could not be responsible for dental pathologies since pinnipeds swallow food without chewing or slicing, as discussed above.

\section{Acknowledgements.}

Dr. B.K.Hall, Dr. M.J.L.Stiassny and Dr. J.Gatesy supported us with important manuscripts before publication. Peter Adam provided important paleontological informations. To all institutions curators: Dr. E.A.Crespo and N.Garcia (CENPAT); D.Szetern, A. Le Bas and A.Mones (Montevideo), O.Vaccaro, G.Daneri and L.H.Cappozzo (MACN); J.Ferigolo, M.Martins and G.Bencke (MCN). A special thanks to D.Janiger for sending us important electronic papers. Dr. Mario
Cozzuol, Claudia R. F. de Carvalho and Mônica Muelbert offered important comments on the manuscript. Dr. Katharina Dittmar de la Cruz kindly reviewed a final version of the manuscript. To S.Amato and G.BondBuckup in the name of UFRGS/PPG-BAN.

\section{References}

Andrews, R.C. (1921) A remarkable case of external hindlimb in a humpback whale. American Museum Novitates 9: 1-6.

Barnes, L.G. (1989) A new Enaliarctine pinniped from the Astoria Formation, Oregon, and a classification of the Otariidae (Mammalia: Carnivora). Contributions in Science (403): 1-26.

Bejder, L. and Hall, B.K. (2002) Limbs in whales and limblessness in other vertebrates: mechanisms of evolutionary and developmental transformation and loss. Evolution and Development 4(6): 445-458.

Berta, A. (1994) New specimens of the Pinnipediform Pteronarctos from the Miocene of Oregon. Smithsonian Contributions in Paleobiology 78: iii $+30 p$.

Berta, A. and Deméré, T.A. (1986) Callorhinus gilmorei n. sp., (Carnivora, Otariidae) from the San Diego Formation (Blancan) and its implications for otariid phylogeny. Transactions of San Diego Society of Natural History 21(7): 111-126.

Berta, A. and Sumich, J.L. (1999) Marine Mammals - Evolutionary Biology. Academic Press, San Diego.

Berta, A. and Wyss, A. (1994) Pinniped Phylogeny. Pages 33-56 in Berta, A. and Deméré, T.A. (Eds). Contributions in marine mammal paleontology honoring Frank C. Whitmore Jr. Proceedings of San Diego Society of Natural History 29.

Campagna, C., Le Bouef, B.J. and Cappozzo, H.L. (1988) Group raids: A mating strategy of male southern sea lions. Behavior 105: 224-246.

Chiasson, R.B. (1957) The dentition of the Alaskan fur seal. Journal of Mammalogy 38(3): 310-319.

Commission of Zoological Nomenclature (2000) Opinion 1962. Arctocephalus F. Cuvier, 1826 and Callorhinus Gray, 1859 (Mammalia, Pinnipedia): proposed conservation by the designation of Phoca pusilla Schreber, [1775] as the type species of Arctocephalus; and Otaria Péron, 1816 and Eumetopias Gill, 1866: proposed conservation by the designation of Phoca leonina Molina, 1782 as the type species of Otaria. Bulletin of Zoological Nomenclature 57(3): 193-195.

Crespo, E.A. (1984) Dimorfismo sexual en los dientes caninos y en los cráneos del lobo marino del sur Otaria flavescens (Shaw) (Pinnipedia, Otariidae). Revista del Museo Argentino de Ciencias Naturales Bernardino Rivadavia, Serie Zoología 13(25): 245-254.

Cruwys, E. and Friday, A.E. (1995) A comparative review of condylobasal lenghts and other craniometric characters in 30 species of pinniped. Polar Record 31(176): 45-62.

Dassule, H.R., Lewis, P., Bei, M., Maas, R. and McMahon, A.P. (2000) Sonic hedgehog regulates growth and morphogenesis of the tooth. Development 127: 4775-4785.

Drehmer, C.J. and Ferigolo, J. (1996) Anomalias e patologias dentárias em Arctocephalus G. Saint-Hilaire \& Cuvier (Pinnipedia, Otariidae) da costa do Rio Grande do Sul, Brasil. Revista brasileira de Zoologia 13(4): 857-865.

Drehmer, C.J., Ferigolo, J. and Borsato, E.S. (1998) Ocorrência de Mirounga leonina Linnaeus (Pinnipedia, Phocidae) no extremosul do Brasil: agressão e patologias. Revista Brasileira de Zoologia 15(4): 1061-1068.

Erb, E., Shaughnessy, P.D. and Norman, R.J. de B. (1996) Dental and mandibular injury in an Antarctic fur seal, Arctocephalus gazella, at Heard Island, Southern Ocean. Journal of Wildlife Research 32(2): 376-380. 
Feldhamer, G.A. and Stober, T.L. (1993) Dental anomalies in five species of North American shrews. Mammalia 57(1): 115-121.

Gatesy, J., Amato, G., Norell, M., Desalle, R. and Hayashi, C. (2003) Total evidence support for iterated taxic atavism in Gavialine Crocodylians. Systematic Biology 52(3): 403-422.

Gardner, A.L. and Robbins, C.B. (1999) Case 3058. Arctocephalus F. Cuvier, 1826 and Callorhinus Gray, 1859 (Mammalia, Pinnipedia): proposed conservation by the designation of Phoca pusilla Schreber, [1775] as the type species of Arctocephalus; and Otaria Péron, 1816 and Eumetopias Gill, 1866: proposed conservation by the designation of Phoca leonina Molina, 1782 as the type species of Otaria. Bulletin of Zoological Nomenclature 56(2): 136-141.

Gorlin, R.J., Cohen, M.M. Jr. and Hennekam, R.C.M. (2001) Syndromes of the Head and Neck. Oxford University Press, Oxford.

Hall, B.K. (1984) Developmental mechanisms underlying the formation of atavisms. Biological Reviews of the Cambridge Philosophical Society 59: 89-124.

Hall, B.K. (2003) Descent with modification: the unity underlying homology and homoplasy as seen through an analysis of development and evolution. Biological Reviews of the Cambridge Philosophical Society 78: 409-433.

Hall, E.R. (1940) Supernumerary and missing teeth in wild mammals of the orders Insectivora and Carnivora with some notes on disease. Journal of Dental Research 19: 103-143.

Hancox, M. (1988) Dental anomalies in the Eurasian badger. Journal of Zoology 216: 606-608.

Heath, C.B. (2002) California, Galapagos, and Japanese sea lions. Pages 180-186 in Perrin, W.F., Würsig, B., Thewissen, J.G.M. (Eds) Encyclopedia of Marine Mammals. Academic Press, San Diego.

Hoff, G.L. and Hoff, D.M. (1996) Dental anomalies in mammals. Pages 100-108 in Fairbrother, A., Locke, L.N., Hoff, G.L. (Eds) Noninfectious diseases of wildlife. Iowa State University Press, Ames.

Jiménez, B., González, M.J., Hernández, L.M., Eljarrat, E., Rivera, J. and Fossi, M.C. (1999) 2, 3, 7, 8- substituted PCDDs and PCDFs in sea lion (Otaria flavescens) skin biopsies from two southwestern Atlantic populations. Chemosphere 38(3): 507-515.

King, J.E. (1964) Seals of the world. British Museum of Natural History, London.

Koen Alonso, M., Crespo, E.A., Pedraza, S.N., Garcia, N.A. and Coscarella, M.A. (2000) Food habits of the South American sea lion, Otaria flavescens, off Patagonia, Argentina. Fishery Bulletin 98: 250-263.

Kubota, K. and Togawa, S. (1964) Numerical variations in the dentition of some pinnipeds. Anatomical Record 150: 487-502.

Kvam, T. (1985) Supernumerary teeth in the European lynx, Lynx lynx lynx, and their evolutionary significance. Journal of Zoology 206: 17-22.

Lande, R. (1978) Evolutionary mechanisms of limb loss in tetrapods. Evolution 32: 73-92.

Line, S.R.P. (2003) Variation of tooth number in mammalian dentition: connecting genetics, development, and evolution. Evolution and Development 5(3): 295-304.

Marshall, C.R., Raff, E.C. and Raff, R.A. (1994) Dollo's Law and the death and resurrection of genes. Proceedings of the National Academy of Sciences, U.S.A. 91: 12283-12287.

Mathisen, O.A., Baade, R.T. and Lopp, R.J. (1962) Breeding habits, growth and stomach contents of the Steller sea lion in Alaska. Journal of Mammalogy 43(4): 469-477.

Mendez, E. and Rodriguez, B. (1984) A southern sea lion, Otaria flavescens (Shaw) found in Panama. Caribbean Journal of Science 20(3-4): 105-108.

Miyazaki, N. (2002) Teeth. Pages 1127-1232 in Perrin, W.F., Würsig, B., Thewissen, J.G.M. (Eds) Encyclopedia of Marine Mammals. Academic Press, San Diego.
Mora-Pinto, D.M. and Muñoz-Hincapié, M.F. (1995) Marine mammal mortality and strandings along the Pacific coast of Colombia. Reports of International Whaling Commission 45: 427-429.

Raikow, R.J. (1975) The evolutionary reappearance of ancestral muscles as developmental anomalies in two species of birds. Condor 77: 514-517.

Raikow, R.J., Borecky, S.R. and Berman, S.L. (1979) The evolutionary re-establishment of a lost ancestral muscle in the bowbird assemblage. Condor 81: 203-206.

Reppening, C.A. and Tedford, R.H. (1977) Otarioid seals of the Neogene. Geological Survey Professional Paper 992, vi + 93p +24 pls.

Riedl, R. (1977) A systems-analytical approach to macroevolutionary phenomena. Quarterly Review of Biology 52(4): 351-370.

Sivertsen, E. (1954) A survey on the eared seals (family Otariidae) with remarks on the Antarctic seals collected by $M / K$ "Norvegia" in 1928-1929. Scientific Results of the Norwegian Antarctic Expeditions, 36. Det Norske Vidskaps Akademi I Oslo.

Stewart, R.E.A. and Stewart, B.E. (1987) Mandibular dental anomalies of Northwest Atlantic harp seals, Phoca groenlandica. Canadian Journal of Zoology 65: 769-771.

Stiassny, M.L.J. (1992) Atavisms, phylogenetic character reversals, and the origin of evolutionary novelties. Netherlands Journal of Zoology 42: 260-276.

Szapkievich, V.B., Cappozzo, H.L., Crespo, E.A., Bernabeu, R.O., Comas, C. and Mudry, M.D. (1999) Genetic relatedness in two Southern sea lion (Otaria flavescens) rookeries in the southwestern Atlantic. Zeitschrift für Saugetierkunde 64: 1-5.

Tedford, R.H., Barnes, L.G. and Ray, C.E. (1994) The Early Miocene littoral ursoid carnivoran Kolponomos: systematics and mode of life. Pages 11-32 in Berta, A. and Deméré, T.A. (Eds) Contributions in marine mammal paleontology honoring Frank C. Whitmore Jr. Proceedings of San Diego Society of Natural History, 29.

Thesleff, I. (2000) Gentic basis of tooth development and dental defects. Acta Odontologica Scandinavica 58(5): 191-194.

Vaz-Ferreira, R. (1981) South American sea lion Otaria flavescens (Shaw, 1800). Pages 39-65 in Ridgway, S.H. and Harrison, R.J. (Eds) Handbook of Marine Mammals, vol.2, Seals. Academis Press. London.

Vaz-Ferreira, R. (1982) Otaria flavescens (Shaw), South American sea lion. Pages 477-495 in Mammals in the seas. FAO Fisheries series 4(5): 477-495.

Vila, B.L. and Cassini, M.H. (1990) Agresividad entre hembras y separación madre-cría en el lobo marino del sur, en Chubut, Argentina. Revista Chilena de Historia Natural 63: 169-176.

Waddington, C.H. (1975) The evolution of an evolutionist. Cornell University, xii $+328 \mathrm{p}$.

Wederlin, L. (1987) Supernumerary teeth in Lynx lynx and the irreversibility of evolution. Journal of Zoology 211: 259-266.

Wellington, G.M. and De Vries, T. (1976) The South American sea lion, Otaria byronia, in the Galapagos Islands. Journal of Mammalogy 57(1): 166-167.

Wolsan, M. (1984) The origin of extra teeth in mammals. Acta Theriologica 29(10): 128-133.

Wozencraft, W.C. (1989) The phylogeny of the recent carnivora. Pages 495-535 in Gittleman, J.L. (Ed.) Carnivore behavior, ecology and evolution. Cornell University, Ithaca.

Wynen, L.P., Goldsworthy, S.D., Insley, S.J., Adams, M., Bickham, J.W., Francis, J., Gallo, J.P., Hoelzel, A.R., Majluf, P., White, R.W.G. and Slade, R. (2001) Phylogenetic relationships within the eared seals (Otariidae, Carnivora): implications for the historical biogeography of the family. Molecular Phylogenetics and Evolution 21(2): 270-284.

Wyss, A.R. (1988) On "retrogression" in the evolution of the Phocinae and phylogenetic affinities of the monk seals. American Museum Novitates 2924: 1-38. 


\section{APPENDIX 1}

Specimens data: ZVCM 28, Isla de Lobos, Uruguay, adult O' , R.Vaz-Ferreira and E.Palerm col., 1952; ZVCM 29, Isla de Lobos, Uruguay, adult $\sigma^{\prime \prime}$, R.Vaz-Ferreira and E.Palerm col., 6/VII/1952; ZVCM 331, Isla de Lobos Uruguay, subadult O", R.Vaz-Ferreira and E.Palerm cols., 10/VIII/1965; MNHN-M 2785, Depto. Rocha, Uruguay, adult O"; MCN 2459, Santa Vitória do Palmar, Brazil, adult O', J.Ferigolo col., IX/1990; MCN 2505, Mostardas, Brazil, adult ర̃ , C.Drehmer col., 22/VIII/1992; MCN 2695, São José do Norte, Brazil, juvenile O', C.Drehmer, E.Borsato and M.Rosenau cols., 17/IX/1995; MCN 2697, Santa Vitória do Palmar, Brazil, adult o" , C.Drehmer, E.Borsato and M.Rosenau cols., 18/IX/1995; MACN 260, Tierra del Fuego, Argentina, adult O' ; MACN 20583, Atlantic, adult O" ; MACN 20595, Atlantic, subadult 우; MACN 21738, Punta Bermeja, Argentina, adult 우, E.A.Crespo col., I/1982; MACN 21743, Chubut, Argentina, subadult O', A.M.Giudice col., 10/II/1990; MACN 21744, Puerto Madryn, Argentina, juvenile $0^{\prime \prime}$, E.Crespo col.; MACN 25168, Argentina, adult O' ; MACN 41226, Atlantic, adult O' ; CNP 34, Chubut, Argentina, adult O", J.Upton col., 1979; CNP 36, Isla de Lobos, Argentina, juvenile O', Rodriguez col.; CNP 43, Punta Bermeja, Argentina, subadult O' , E.Crespo col., I/1982; CNP 48, Punta Bermeja, Argentina, juvenile E.Crespo col., III/1982; CNP 75, Enseada Medina, Argentina, juvenile ㅇ , E.Crespo col., 19/VII/1982; CNP 105, Puerto Madryn, Argentina, subadult O', M.Lewis and J.Upton cols., 11/VIII/1982; CNP 106, Puerto Madryn, Argentina, juvenile O", J.Upton col., IX/1982; CNP 115, Punta Norte, Argentina, juvenile O' , E.Crespo col., X/1982; CNP 134, Punta León, Argentina, juvenile O', E.Crespo col., 27/VII/1983; CNP 152, Punta Hércules, Argentina, adult O' , E.Crespo col., 13/IV/1984; CNP 157, Punta Hércules, Argentina, adult O' , E.Crespo col., 13/IV/1983; CNP 178, Punta León, Argentina, adult 우, E.Crespo and J.Upton cols., 7/XII/1984; CNP 187, Punta León, Argentina, adult O' ; CNP 198, Argentina, adult 우; CNP 199, Argentina, adult O' , E.Crespo col., 22/II/1985; CNP 220, Monte Loayza, Argentina, juvenile, unknown sex, E.Crespo col., VII/1990; CNP 244, Punta Delgada, Argentina, adult O', N.Garcia col.; CNP 255, Golfo San Matias, Argentina, adult O', S.Dans, N.Garcia and E.Crespo cols., 7/II/1993; CNP 258, Islote Lobos, Argentina, juvenile O" , E.Crespo col., II/1993; CNP 259, Puerto Madryn, Argentina, juvenile రం , II/1993; CNP 271, Argentine coast, adult O' , 28/IX/1993; CNP 281, Islote Lobos, Argentina, juvenile 우 , L. Reyes col., 25/XI/1993; CNP 301, Punta Bermeja, Argentina, juvenile O' , II/1994; CNP 312, Isla Vernacci, Argentina, juvenile O' , L.Reyes, 25/I/1994; CNP 334, Isla Ceballos, Argentina, juvenile O', L.Reyes col., 26/I/1994; CNP 399, Punta Alt, Argentina, adult ㅇ , R.Vera col.; CNP 419, Isla Leones, Argentina, subadult O' , L.Reyes col., 19/X/1995; CNP 437, Isla Gran Robredo, Argentina, juvenile unknown sex; CNP 442, Puerto Madryn, Argentina, subadult + , N.Garcia col., 16/II/1996; CNP 447, Isla Vernacci Oeste, Argentina, juvenile 우, L.Reyes col., 26/I/1996; CNP 455, Punta Ameghino, Argentina, adult 우 ,N.Garcia col., 26/IV/1996; CNP 456, Playa Parana, Argentina, juvenile O' , E.Crespo and N.Garcia cols.; CNP 457, El Doradillo, Argentina, subadult O', 21/VIII/1996; CNP 467, Punta Buenos Aires, Argentina, adult 우, N.Gracia and M.Alonso cols., 21/I/1997; CNP 468, Punta Buenos Aires, Argentina, Argentina, juvenile O" , N.Gracia and M.Alonso cols., 21/I/1997; CNP 476, Playa Barco Hundido, Argentina, adult O" , E.Crespo, P.Ott and E.Secchi cols., 18/VIII/1997; CNP 491; Punta Tafor, Argentina, adult 오 , L.Cappozzo and E.Crespo cols., 23/II/1998; CNP 500, Playa Parana, Argentina, adult O', E.Crespo col., 15/XII/1998; CNP 511, Argentine coast, subadult O" ; CNP 513, Isla Arce, Argentina, juvenile O", E.Crespo col., 17/XII/1996; CNP 515, Puerto Madryn, Argentina, subadult +9 , M.Alonso, E.Crespo and R.Gonçalves cols., 3/XII/1999; CNP 527, Punta Buenos Aires, Argentina, juvenile O', N.Gracia col., 26/I/2000; CNP 531, Punta León, Argentina, adult O', N.Gracia col., 2/II/ 2000; CNP 547, Playa Barco Hundido, Argentina, adult 오, N.Garcia col., 26/VIII/2000; CNP 553, Puerto Madryn, Argentina, adult O', N.Garcia col., 28/IX/2000; CNP 560, Islote Moreno, Argentina, adult ㅇ , N.Garcia, E.Crespo and M.Alonso cols., 13/XII/2000. 